\title{
Impact of Leadership in Successful Management of Education
}

\author{
Prof. asc Sanie DODA \\ Lecturer, Aleksander Moisiu University \\ Durres, Albania \\ E-mail: sanijedoda@yahoo.com
}

Received: Jan. 9, 2018 Accepted: Jan. 26, 2018 Online published: Feb. 2, 2018

doi:10.5296/ijhrs.v8i1.12584 URL: https://doi.org/10.5296/ijhrs.v8i1.12584

\begin{abstract}
In the era of the development of information and communication technology, the use of this technology during the teaching process has become a necessity for teachers. This development is directly related to the updating of new knowledge and skills in the field of education. The method by which leaders or managers put members of an organization to do something collectively to achieve their goals is used to develop a style-based leadership style. Technology has the power and the potential to transform the professional teaching environment. To be a successful leader in academic institutions needs to meet many demands, similar to those required in other sectors. But the multiplicity of complexities, the variety of objectives for fulfilling sometimes conflicting obligations, the motivational factors of individual academics, and the variety of different management interpretations in this sector are special. Universities are complex organizations and as such pose major leadership challenges. This creates the need for leadership leadership and careful management. Since universities have become very autonomous, in most countries, they have been encouraged to be more market-oriented and to link their development more to the labor market and the local economy.
\end{abstract}

Keywords: leadership, education, university, organization, management

\section{Understanding Leadership}

In English speaking countries Leadership derives from the ancient Anglo-Saxon word 'loedan', meaning a path, a road, or a journey. And this simple definition has been used throughout our "journey" through the labyrinths of leadership. The essence of leadership is often considered to be the ability to orient people in new directions, to orient them in countries that did not know they wanted or needed to go. Leadership is the exercise of authority to guide the work of others 


\section{Macrothink}

International Journal of Human Resource Studies

ISSN 2162-3058

2018, Vol. 8, No. 1

(Inman. M, 2007: 147). Leadership can be formal or informal. When exercising authority, leadership is about activating people to do something the leader wants in pursuit of an organization's goals. Politologist scientists John Harrigan and David Lawrence, for example, characterize the leadership of senior executives-whether they governors, mayors, lecturers, or presidents, as one of four distinct styles: demagogue, careers, policy entrepreneurs, and disappointed leaders (Cary L. Cooper, 2005: 30).

Demagogue. In this case, he provides support by "harassing" emotions and prejudices.

Caring. In this case, we are dealing with a "politically conservative" leader who prefers maintaining the existing situation.

Policy makers. Here we are dealing with senior executives who undertake reforms, are very active to move forward developments, who not only propose new programs but also enable their funding and implementation (Starkey. K and Tempest. S, 2004: 42).

Leader disappointed. In this case, the leader is an improper policy entrepreneur who is incapable of fulfilling his vision (Blush. T, 2008: 105). In this case, his efforts end in disappointment. Judged as a leader, pedagogues are also characterized by different types of personality examples., Scientist James Barber classifies pedagogues in four types:

Active - Positive. Such are the ones who are above all oriented towards achieving the results.

1. Active - Negative. This group includes those who intend at all costs to take up and preserve the main post.

2. Passive - Positive. These include those faculty who ask students to love and honor you.

Passive - Negative. These pedagogues emphasize the value of the study.

Leadership in higher education is generally exercised by department managers. In this way leadership is exercised within a given background or organizational situation.

The organizational context influences the style and approach to leadership as it affects the personality and professional experience of the latter on the organization itself. It is precisely this organizational context that affects the legitimacy of the leader. How well the leader's characteristics and abilities affect the achievement of organizational goals help or hinder the legitimacy given to the manager (Rhind. D., 2005: 309).

Knight and Trowler (2001) have listed leadership and knowledge management skills that think an academic leader should have;

- Define the mission and goals,

- To be seen as the institutional incarnation of goals,

- Protect the integrity of the University

- Decide when there are internal conflicts.

- Knowledge and ability to control

- Know about educational practices.

- Conceptual Knowledge (to know about concepts and research about leadership and management).

- Knowledge of Processes (leadership and management processes).

- Knowledge and Skills of Situations (understand the uncertainties that a faculty has become 
and what impact it can be in the future as such).

- Understandable knowledge, which integrates the above-mentioned 6th forms into qualification practices.

Leadership discussed in the context of a University includes three distinct levels of responsibility and control:

1. Tech,

2. Managerial, and

3. Institutional.

Asked "Who is the leader"? in this context we are re-formulating (leaving too many definitions given again) we are giving perhaps the most acceptable definition as follows:

The leader is defined as any person who influences individuals and groups within the organization, helps them in defining objectives and guides them towards achieving these goals.

The term "management" itself derives from the French, from the word 'menager' used in the context of the management of a household (Cary L. Cooper, 2005: 30). Another etymological alternative comes from the Italian word 'mannegiare' or horse-handler, which in essence expresses a common and low sense of management, in the sense that management was one that could be done by anyone.

\section{Leadership or Management?}

The concept of leadership in education and management is overlapping. One of the clearer definitions of the distinction between leadership and management is the one that links leadership with change while managing the organization's performance well. Also, both of these dimensions are of great importance in organizing the activity (Starkey. K and Tempest. S, 2004: 8). Through different texts or studies we find many types of comparisons and differences for these two terms, but those that will be listed below are quite significant and with a prominent practical sense:

1. Leadership is usually concerned with what needs to be done - management focuses on how things should be done. From here we can say that the manager focuses on how quickly and efficiently an employee climbs up and down to a degree to do the job. While the leader's primary occupation would be to determine whether the scale was supported on the right wall.

2. Leadership is first and foremost preoccupied with relationship-management is often preoccupied with the task. From here we can say that the manager dealing with the conflict between the two subordinates will try to rely on the power of the position and the procedural rules for his resolution. The leader would attempt to use personal power and authority, communication skills, and skills to appeal to the heart and mind of his followers to resolve the conflict.

3. Leaders should think outside the box-managers usually think inside it. So, management is about employee efficiency now and here, while leadership is about making change, which will enable staff to be efficient in the future.

4. Leaders try to find ways to enhance and improve employee performance, managers are mostly concerned with performance controls and monitoring. Consequently, managers tend to push their staff towards the goals they have set for you. Leaders will focus their energies to 


\section{Macrothink \\ International Journal of Human Resource Studies \\ ISSN 2162-3058 \\ 2018, Vol. 8, No. 1}

attract staff to the goals they have set together.

5. Leaders feel good about change and possess an orientation from the outside, towards change, towards the future. Managers may feel uncomfortable from the perspective of change and often focus on maintaining the status quo.

6. Leaders are able to walk towards the unknown - managers often have to say / show why this should be done. So leadership is often concerned with the creation of new paradigms, managers often focus on operating within the existing paradigm.

The difference between leadership and management is also applied by Watson to $7 \mathrm{~S}$ 's organizational framework: Strategy, Structure, Systems, Styles, Staff, Skills, and Shared Goals. Watson suggests that while managers tend to rely on strategy, structure and systems, leaders have a permanent tendency towards "soft" S: style, staff, skills, and common goals. He also suggested, though with reservation that the $7 \mathrm{~S}$ should be seen as a domain of leadership. Managers are usually unable to achieve such a mastery of 7 factors to achieve a high level of organizational performance on an ongoing basis.

Management is to effectively and efficiently carry out the procedures and outcomes in an organization, that is, the "process of doing things". While management occasionally displays leadership skills, the whole function that it really has is the one of the changing things in the organization. Managers often have a formal position in the organization, and you are always assigned by someone else to these leadership positions (Starkey . K and Tempest. S, 2004: 42). It is widely accepted that different leadership styles can succeed, but that style of leadership that is successful in one country may not succeed in similar situations elsewhere or in a later period.

Leadership Models in Education and Management.

The Variety of Leadership Theories in Education and Management reflects different ways of understanding and understanding behaviors in schools and universities. They show how the educational institutions should be managed (Cary L. Cooper, 2005: 30).

These models mentioned below are a compilation of the main theories of Leadership in Education and are divided into 6 types:

Typology of Leadership and Management Models

\section{Management Models}

1. Formal

2. Collegial

3. Politics

4. Subjective

5. Ambiguity

6. Cultural

\section{Leadership Models}

1. Managerial

2. Participant

3. Transformational 
4. Interpersonal

5. Operational

6. Postmodern

7. Uncertainty

8. Moral

9. Instuctional

But what links exist between management models and those of leadership in education?

Based on the fact that in different institutions of higher education institutions are tested and tested different models that link management with the situation, or even the same suggestions made in different environments, point to the necessity of having a logical connection based on situational influences, between leadership typologies and leadership patterns. These come in the form of pairs between managerial models and corresponding leadership models where the most important for the management of higher education institutions are the Formal Management and the Management Model; Collegium Management and Participatory Modeling, Political Management and Transaction Model, Subjective Management and Post-Modern Modeling and Lastly, Ambiguity Management and Leadership Modeling Modeling.

Regardless of what particular paths and actions may suggest, the suggested models have some structural and logical elements that make up their axis and should be taken into account by enforcers such as referrals to structure, referrals to the system, references to bureaucracy, rationality, and ultimately hierarchy (Knight, P. and Trowler, P., 2001: 8).

At the same time, the differences in the actions undertaken by the higher education institutions, which show the way of defining the mission, their priorities and their deployment, can be seen here. So the more formal the patterns used are, the more attention the hierarchy and the authority have, the more the system is oriented towards a goal that has been established and has accepted the roles that derive from it.

Collegial models of leadership in higher education institutions have a normative orientation and are a good way of running in those institutions where there are a considerable number of members of specialized and administrative academic staff (Rhind. D 2005: 310).

Likewise, direction through them reflects a set of values that affect the climate of trust and organizational co-operation.

Participatory Leadership sets a broad decision-making framework and reduces the opportunities of a "heroic" leadership when the powers are scattered within the institution.

While transformational leadership is better coordinated with the collegial model, always with the assumption that the leader and the staff have the same values and beliefs, the participatory leadership is at the center of its focus group decision-making and guarantees the principles of enhancing the effectiveness of the higher education institution, maintaining the principles of democracy and here leadership is in line with the interests of all stakeholders of the university or faculty (Rhind. D, 2005: 313). Political models are more focused on activities than on the institution as a whole and tend to focus on interests and interest groups. Likewise, they spread the conflict in the educational institution. 


\section{MInstitute Macrothink $_{\text {Ins }}$}

International Journal of Human Resource Studies

ISSN 2162-3058

2018, Vol. 8, No. 1

Under such conditions, Transactional Leadership naturally goes where relationship with executives and pedagogues is that of exchanging a relatively valued and sought source. Political models put the focus of organizational actions on the interests of particular groups and are heavily submerged in conflict and manipulation and neglect other standards of the organization. The great importance attached to the conflict decreases the possibilities of cooperation among the members of the organization, thus reducing the attention to the teaching process and the student's progress (Inman. M, 2007: 48). Subjective models focus even more on the interests of a particular individual than those of the organization. This implies that everyone within the organization has a perception of the organizational environment, which makes the organization even more complex as a summary of these subjectivisms. So the organization, in this perspective, is a creature of people within it and their interpretations depend on everybody's background. Subjective models rely more on the beliefs and perceptions of individual members than on the institutional level or the interests of the groups. They rely more on subjective meaning given to events, in individual significance of events than in situations and actions ${ }^{1}$. Subjective models treat the structure as a product of interactions between participants in the organization rather than as something fixed and predetermined. The organizational charters themselves consider it a scheme that can not predict the behaviors of individual individuals within it. These models emphasize the gravity of individual goals and deny the existence of the organization's goals.

However, this type of model has an irreplaceable impact on Scientific Research as a few other models of leadership in Higher Education Institutions because they focus on individuals rather than organizations, and it is clear that support to individual intuition is essential to one Successful scientific research (Blush. T, 2008:105). Also, the performer needs to give meaning to the findings, interpretations of events and people. At the same time, search results are interpreted using ground based theories.

The Postmodern Leadership that coincides with the Subject Model emphasizes the individual's abilities and capabilities rather than his position in the organization (Inman. M, 2007: 47).

In this context, the leader should give the cultural context and meanings that individuals give to the institution and the activities within it.

The ambiguity model puts uncertainty and ambiguity into higher education institutions.

Heads of institutions applying such models in universities and faculties are based on the principle that the objectives that could be placed on the institutions are problematic, and these cause problems in prioritizing their own.

Below units are seen as independent and isolated and very little interoperable with each other in the organizational framework.

Ambiguity seems to be so prevalent in universities and faculties especially in conditions of immediate change.

At the same time, it seems that these theoretical premises find support in the speed with which the higher education environment changes in many respects, where technologies evolve but are

\footnotetext{
${ }^{1}$ https://www.oecd.org/edu/school/44374889.pdf
} 
not understood, alliances and preferences also vary, problems solutions and ideas relate to such a way with each other that complicate even more this kind of complexity.

\section{Does the Context Affect the Management of Education?}

Both Management, and Leadership, in the context of educational institutions are seen as practical activities. However, the application of theories in practical situations is seen by experts as a difficult thing.

From this point of view, the gap between theories and practice can only be managed if the theories or models to be applied in educational institutions are preceded by scenarios and anticipated practical effects (Rhind. D 2005: 305).

However, there is a great influence on the management and management of educational institutions, how a model is built and applied and not just an intuitive orientation based on facts.

This is because, first of all, relying simply on the facts as a basis for action requires their own interpretation, which in many cases require interpretation, makes the process subjective.

Secondly, leadership in action simply from the personal experience of the leader leaves nothing to do with the experience of other members of the institution. Theories in this case use a wider experience (Inman. M, 2007: 148).

Finally, we need to keep in mind that changing the educational context (as it continues to happen in Albania), making experiences as the only guiding tool for action, is not enough, bringing theoretical models suggestions first.

Each of them has something to offer in explaining behaviors and situations in educational institutions, but anyway, angles of managerial, articulated or not, will inevitably influence decisions-making.

From a thorough and detailed analysis of the functioning, governance, organization and accreditation of HEIs, as well as the assessments made by local and foreign institutions (MAS, BB, UNICEF, UNDP) for years, of higher education in Albania presents a number of complex problems and does not fully respond to the current and future needs of the country's development both in terms of teaching and research work.Higher education system evaluations in Albania show that it carries issues in several respects, at different levels. These issues in some cases have not allowed the system to form professionals to meet the demands of the time and the labor market. Among the most important problems is the lack of teaching-related interaction with scientific research work. A direct indication of this anomaly is the existence of two separate Laws on Higher Education and Science, reflected in the entire organization of higher education in the country. It is also noted the wrongful implementation or misapplication of the current law on higher education, regardless of the problems it presents in itself, both by central government institutions and by the HEIs. This happens for various reasons related to both the human factor and the lack of assessment and control mechanisms in any system link. Annual reports by HEIs are not always transparent and there is sometimes no real analysis of their situation at all levels, ranging from the quality of teaching to the standard of scientific research. Accountability in some cases is at a minimum level ${ }^{2}$.

\footnotetext{
${ }^{2} \mathrm{https} / / /$ ec.europa.eu/epale/sites/epale/files/raport-studimin-etika-ne-sistemin-arsimor-ne-shqiperi.pdf
} 
The rapid developments of the higher education system in Albania have brought about overlapping of the academic offer of HEIs and the lack of better matching of learning outcomes with market needs. Another weakness of the system is the emphasis on centralization and vertical decision making (Inman. M, 2007: 149).

This is also caused by the lack of autonomy and full impartiality in making decisions by the above-mentioned national agencies and councils. Another problem of the system is the interference with by-laws of the Council of Ministers and the MAS, which, from time to time, have not helped the sustainable development of higher education, and in a few cases have also violated that autonomy of guaranteed by law for HEIs.

\section{Conclusions and Recommendations}

$>$ In many countries around the world, there is no recognition that schools require effective Leaders and Managers if they are to provide the best possible education for their students.

$>$ Successful leadership should enjoy some qualities where the most important are: communication; tolerance, ambition to move forward etc.

$>$ The successful leader also seeks recognition of staff achievements as an important element of their self-assessment. It requires skills to enhance the name image, fundraising, and make frequent changes in access to vibrant universities.

$>$ The Albanian Higher Education System during the last 20 years has sailed through continuous and drastic transitions. They are still happening at present by raising a series of questions and dilemmas for Institution managers, part of this system.

$>$ Based on the best international experiences, while the state's approach to higher education is changing, it is also necessary to change the full institutional autonomy of HEIs in Albania. This autonomy can not be fully achieved if there is no change in the status of public HEIs, whereby this autonomy is guaranteed by law.

$>$ The purchasing power of Albanian families is not such as to cope with a strong non-public system where there are competitive tariffs to guarantee one of the main principles of equal competition.

$>$ Another argument for moving towards the calculation of higher education statuses in Albania is the fact that the market in Albania is small and, as such, the principle of genuine competition can not be implemented by having a large number of institutions with different statuses.

$>$ Higher education institutions in Albania should provide teaching not only in Albanian, but at least in English, with the aim of opening curriculum studies of interest to researchers and researchers from other developed countries, as well as to create a real opportunity for institutional cooperation and partnership with European and wider societies. .

$>$ Today, higher education is public and non-public, where the latter is lucrative and not lucrative.

$>$ The Commission estimates that in the long run, while allowing diversity and the choice of higher education institutions, go to effective and competitive university structures. 
$>$ In the commission's assessment, organization as foundations or similar structures that allow dexterity in orientation towards development, both for public and non-public institutions, is the future that will consolidate the success of the long-term reformation of the education system.

$>$ Further legal changes and, no doubt, changes in the Constitution of the Republic of Albania are required, at least in terms of their definition as public and non-public institutions, as well as the change of status from autonomous institutions to independent institutions in the exercise of authority.

\section{References}

Blush, T. (2008). Leadership and Management Development in Education, Sage Publications: 4,105 .

Cary, L. C. (2005). Leadership and Management in the $21^{\text {st }}$ Centery, Business challenges of the future, Oxford University Press: 30

https://ec.europa.eu/epale/sites/epale/files/raport-studimin-etika-ne-sistemin-arsimor-ne-shqip eri.pdf

https://www.oecd.org/edu/school/44374889.pdf

Inman, M. (2007). The Jurney toLeadership - a study of how leader - academics in High Education learn to lead, University of Birmingham: 147 - 149

Knight, P., \& Trowler, P. (2001). Departmental Leadership in Higher Education: new directions for communities of practice. Buckingham: Open University Press/SRHE: 8

Rhind, D. (2005). Herding Cats or Luxurating in Talent? Leadership and Management of Universities, $305-313$

Starkey, K., \& Tempest, S. (2004). Late Twentieth Centery Management, the Business school and Social Capital, Oxford: Oxford University Press: 42.

\section{Copyright Disclaimer}

Copyright for this article is retained by the author(s), with first publication rights granted to the journal.

This is an open-access article distributed under the terms and conditions of the Creative Commons Attribution license (http://creativecommons.org/licenses/by/4.0/). 